\title{
Ecosystem-Wide Impacts of Deforestation in Mangroves: The Urabá Gulf (Colombian Caribbean) Case Study
}

\author{
J. F. Blanco, ${ }^{1}$ E. A. Estrada, ${ }^{1}$ L. F. Ortiz, ${ }^{1}$ and L. E. Urrego ${ }^{2}$ \\ ${ }^{1}$ Instituto de Biología, Universidad de Antioquia, Medellín, Colombia \\ ${ }^{2}$ Departamento de Ciencias Forestales, Universidad Nacional de Colombia, Medellín, Colombia
}

Correspondence should be addressed to J. F. Blanco, blanco@exactas.udea.edu.co

Received 30 March 2012; Accepted 10 May 2012

Academic Editors: A. Pusceddu, S. Sabater, M. van Noordwijk, and G. Zotz

Copyright ( $) 2012$ J. F. Blanco et al. This is an open access article distributed under the Creative Commons Attribution License, which permits unrestricted use, distribution, and reproduction in any medium, provided the original work is properly cited.

\begin{abstract}
Mangroves are ecologically important and extensive in the Neotropics, but they are visibly threatened by selective logging and conversion to pastures in the Southern Caribbean. The objective of this paper was to summarize the impacts of both threats on forest structure, species composition, aboveground biomass and carbon reservoir, species introgressions, and benthic fauna populations by collating past and current data and by using an interdisciplinary approach in the Urabá Gulf (Colombia) as a case study. Mangroves in the Eastern Coast have been decimated and have produced unskewed tree-diameter (DBH) distributions due to the overexploitation of Rhizophora mangle for poles (DBH range: 7-17 cm) and of Avicennia germinans for planks and pilings $(\mathrm{DBH}>40 \mathrm{~cm})$. Selective logging increased the importance value of the light-tolerant white mangrove Laguncularia racemosa, also increasing biomass and carbon storage in this species, thus offsetting reductions in other species. Introgressions (cryptic ecological degradation) by L. racemosa and Acrostichum aureum (mangrove fern) and low densities of otherwise dominant detritivore snails (Neritina virginea) were observed in periurban basin mangroves. Finally, basin mangroves were more threatened than fringing mangroves due to their proximity to expanding pastures, villages, and a coastal city.
\end{abstract}

\section{Introduction}

Mangroves dominate tropical coasts and provide important services to humans, yet they are one of the most threatened ecosystems partially due to deforestation [1-3]. Mangroves offer provisioning, regulating, supporting, and cultural services [4-6]. Provisioning services are the most commonly appreciated and include sources of timber, fibers and nonwoody products, fuels (firewood and charcoal), food (fisheries), biochemical products, and freshwater; however, the role of mangroves in climatic and hydrologic modulation, erosion control, protection against natural hazards, soil formation, and nutrient cycling has been recently recognized. In addition, different mangrove types (e.g., riverine, fringing, basin) provide specific services and support coastal fisheries to a different extent $[6,7]$, but they may also provide differential carbon capture capabilities [8-11].

Despite the many services offered by mangroves worldwide, deforestation as a consequence of overexploitation of woody products and land reclamation is the most important threat [1-3], although a great local variation is observed $[12,13]$. Deforestation rates in mangroves are four times greater than those in terrestrial tropical rain forests. South American mangroves exhibit the lowest rates compared to Asia, Africa, Northern and Central America; however, a high regional variability is observed, and hotspots do exist [13].

Colombia, located in the northernmost corner of South America, with coasts in both the Caribbean and the Pacific, exhibits the largest annual deforestation rate out of the eight South American countries with mangroves [13]. With $18 \%$ of the region's mangrove cover, deforestation rate in this country (1.1 and $0.6 \%$ ) exceeded the South American average (0.69 and $0.18 \%$ ) in estimates for $1980-1990$ and 2000-2005. These figures may be more variable and dramatic at a subcountry level, bearing in mind that coarse-scale inventories using satellite imagery tend to overestimate mangrove cover due to low spatial resolution and heavy cloud cover (as observed in many areas of the Pacific coast and the Urabá region in the Caribbean coast) [14]. 
Colombia's Caribbean Coast harbors 88250 ha of mangroves strongly threatened by human activities [15-18]. These mangroves have been converted to agricultural lands, shrimp aquaculture ponds, and urban development (mostly for tourism). In addition, extraction of woody and nonwoody products has degraded many mangrove areas thus translating in low stature and slim diameter development [19-21]. Mapping this change has been, however, elusive despite the publication of mangrove cover and conservation status maps by the National Mangrove Inventory Project during the nineties $[17,18]$ and the fine-scale efforts conducted by state-level environmental boards afterwards [21]. Yet most of the information about deforestation remains as grey literature $[15-18,21]$, and, unfortunately, quantitative assessments of mangrove deforestation (using both followup remote sensing and field inventories) at a subnational level are scant and limited to strategic ecoregions such as the Ciénaga Grande de Santa Marta [22]. Mangrove deforestation drivers in the Colombian Caribbean coast may be similar to the observed in the Greater Caribbean Basin $[16,23]$, although rates seem to be lower than the few published examples from México and Panamá, two major Latin American hotspots [13]. For instance, in Quintana Roo (México) an annual deforestation rate of 0.85\% (1995-2007) for fringing mangroves was mostly driven by low-density human settlements and road construction [24]. Despite the tourism activities of the region, this region may be considered a cold spot of deforestation compared to the national average computed during the same period $(1.3 \%$, according to [13]). In the Caribbean region, mangroves have been cleared at a rate of $\approx 1 \% \mathrm{yr}^{-1}$, but figures are greater in mainland than in insular sites $\left(\approx 1.7\right.$ and $0.2 \% \mathrm{yr}^{-1}$, resp. [23]).

In addition to the limited information about rates and drivers of mangrove deforestation, there is a lack of understanding on how specific activities such as selective logging and mangrove reclamation have impacted forest structure, faunal diversity, and services to humans, particularly in the Neotropics. Most of the reliable current knowledge about mangrove change has been obtained by combining coastal land mapping and field surveys in Indopacific locations (e.g., [25-27]). Yet few studies have been able to make historical reconstructions $[24,25,28,29]$. An ethnoecological approach has also proven to be useful for understanding the drivers of deforestation [6, 29-32], while ecological economics have helped to account for the costs of mangrove conversion to other uses in a few case studies (e.g., [33]). Dahdouh-Guebas and Koedam [34] proposed that a transdisciplinary approach is required in order to advance in the knowledge of complex issues such as deforestation and climate change in mangroves.

The objective of this paper was to answer the following questions. (a) To what extent has deforestation impacted mangrove structure, species composition, biomass, and carbon reservoirs? (b) Does deforestation promote proliferation of invasive species such as the white mangrove Laguncularia racemosa and the mangrove fern Acrostichum aureum?, and (c) Is deforestation a driver of declines of keystone benthic fauna? As a case study, we used the Urabá
Gulf (Colombian Caribbean), an ecologically important yet threatened ecoregion located in the northern part of the Biogeographic Chocó biodiversity hotspot $[35,36]$. Historical information about mangrove cover and structure and detailed data obtained during a recent scientific survey were summarized. The ultimate goal of this summary was to contribute insights on the sustainability of current practices of mangrove exploitation.

\section{The Urabá Gulf Mangroves and Deforestation}

The Urabá Gulf (also known as the Darién Ecoregion) is the southernmost location of mangroves in the Caribbean basin (Figure 1), where presumably well-developed and extensive mangrove stands are found, exceeding the figures observed along the Caribbean coasts of Costa Rica, Panamá, and Southern Colombia [18, 37, 38]. Mangrove development is probably boosted by the large freshwater discharge of the Atrato River $\left(Q=4,155 \mathrm{~m}^{3} / \mathrm{s}\right.$, the second largest in the Caribbean Coast of Colombia, after the Magdalena River), fed by the heavy rain of the Chocó Region, one of the world's highest. The most extensive mangroves develop on the deltaic fan of the Atrato River, although smaller areas are found in smaller deltas. This region remained poorly explored by ecologists during most of the 20th century due to public order issues, and mangrove forest inventories were limited to specific areas of interest [35]. These early inventories evidenced that mangroves in the Urabá Gulf were dominated by the red mangrove Rhizophora mangle in most locations while Laguncularia racemosa (white mangrove) and Avicennia germinans (black mangrove) coexisted at lower relative densities. A. germinans formed nearly monospecific stands in the interior (basin) of the Eastern Coast mangroves. These structural and floristic features are more alike to the mangroves in the Pacific coast than to the Caribbean coast of Colombia, probably due to the large freshwater discharge they receive from the Atrato River.

Quantification of deforestation rates and land cover and land use transitions has been impeded by the lack of robust mangrove cover maps. By 2003, it was estimated that 6993 ha of mangroves existed in the Urabá Gulf using satellite images $[17,42]$. The most recent inventory conducted as part of the Urabá Gulf Mangrove Expedition [35, 36] updated mangrove extent and structure using color-high-resolution aerial photographs $(1: 10,000$, pixel size $30 \times 30 \mathrm{~cm})$ taken along a $609 \mathrm{~km}$ coastline, accompanied with field surveys in 79 circular $500 \mathrm{~m}^{2}$-plots during 2009 (Figure 1 and Table 1 in [39]). According to this effort, mangrove cover was estimated in 4908 ha, thus suggesting a reduction in 2085 ha (29.8\%) between 2003 and 2009 (estimated annual rate: $4.9 \%)$. Although this reduction was evidently influenced by deforestation in the region, it was seemly biased by differences in the remote sensing techniques employed in both surveys. Nonetheless, there is no doubt that this region is a deforestation hotspot in the Caribbean coast of Colombia, as evidenced by the field inventory, and observed human uses (see Section 3). While mangroves located in the Atrato River Delta (3846 ha) and the Rionegro Cove (342 ha), the most extensive areas, have seemly experienced 


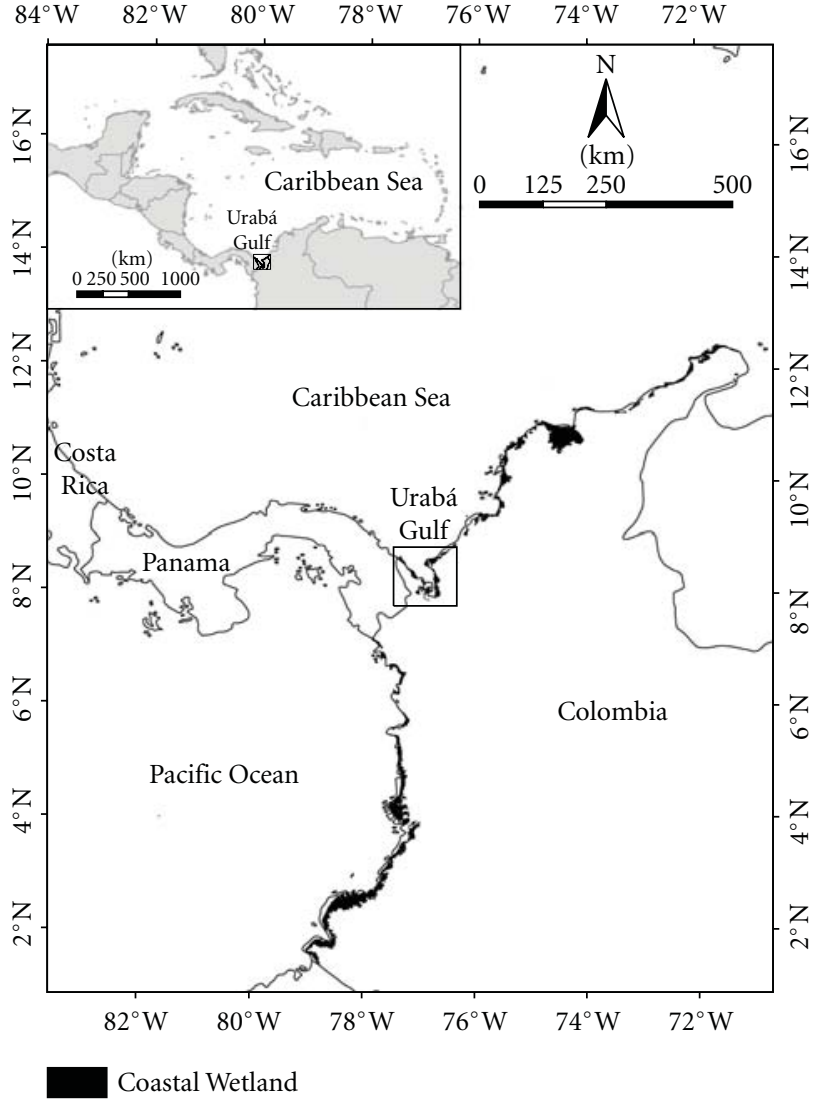

(a)

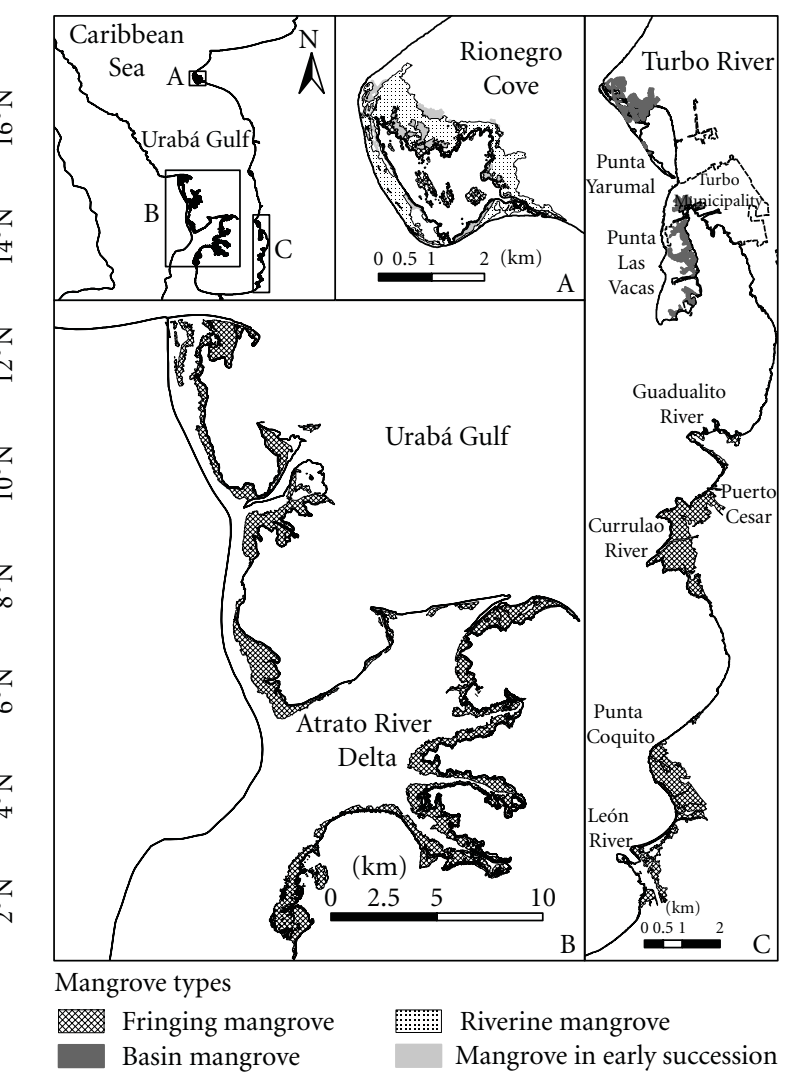

(b)

Figure 1: (a) Location of the Urabá Gulf in Colombia and the Caribbean region (mangrove and coastal flood plain wetlands are shown). (b) Location of mangrove areas in the Urabá Gulf: Atrato River Delta, Rionegro Cove, and the Eastern Coast (Turbo Municipality is shown). Mangrove physiographic types are indicated.

little change in extent during more than two decades, mangroves settled along the Eastern Coast (León River and Punta Coquito: 192 ha; Guadualito and Currulao rivers: 214 ha; Punta Yarumal and Turbo Bay: 145 ha; Caimán Nuevo River: $103 \mathrm{ha}$ ) have been dramatically shrunk due to expanding agricultural and pasture lands and urban areas, particularly near the Turbo Municipality (247 638 inhabitants). Annual population growth rate (1993-2005) in this municipality $(7.2 \%)$ is threefold compared to state- and national-level figures [43]. Population density in 2005 also exceeded national-level values (52 and 41 inhab. $/ \mathrm{km}^{2}$, resp.). Such a population growth has been powered by the profitable banana industry comprising 50359 ha of plantations and exports scoring 55.1 millions of cases [44]. In addition, cattle ranching has been a major economic activity since the early 20th century. For this reason, coastal plain native forests (5048 ha including mangroves) have been decimated and replaced by urban (1499 ha), agriculture (67802 ha), and pasture (142385 ha) [43]. In addition, mangroves along Eastern Coast and the northeastern vicinity of Urabá Gulf have probably shrunken as a consequence of the steady coastline retreat experienced (1-50 m/yr; [45]).

\section{Forest Structure, Species Composition, and Deforestation}

Deforestation alters forest structure and species composition [13]. In the Urabá Gulf, selective logging and land reclamation, in addition to coastline erosion, have reduced mangrove area, but it has particularly altered natural patterns of forest structure and species composition. The early inventories conducted in the most pristine areas (Atrato River Delta and Rionegro Cove) revealed that self-thinning was the most evident driver of structure in red mangrove stands $\left(r^{2}=\right.$ $0.58, P<0.0001$ ) however, a weak self-thinning effect was observed in most transformed areas due to selective logging in the Eastern Coast $\left(r^{2}=0.21, P<0.008\right.$, based on data from [42, 50]). Recently, Urrego et al. [39] reported on the impact of selective logging in suburban mangroves (Table 1). As a reference, $R$. mangle tree diameter was logarithmically skewed towards small values, with a few trees with diameter at breast height $(\mathrm{DBH})>30 \mathrm{~cm}$, in isolated fringing mangroves (Atrato River delta, Rionegro Cove, and Puerto Cesar-Punta Coquito). In contrast, the suburban mangroves located in the vicinity of the Turbo Municipality (Punta 
TABle 1: Area and structure parameters (mean values) for mangroves in the Urabá Gulf. Mangrove species: Rm: Rhizophora mangle, Lr: Laguncularia racemosa, Ag: Avicennia germinans, Pr: Pelliciera rhizophorae. Modified from Urrego et al. [39].

\begin{tabular}{|c|c|c|c|c|c|c|c|}
\hline Location & Mangrove type & Area (ha) & Diameter $(\mathrm{cm})$ & Height (m) & $\begin{array}{c}\text { Basal area } \\
\left(\mathrm{m}^{2} / \mathrm{ha}\right)\end{array}$ & $\begin{array}{l}\text { Density } \\
\text { (ind./ha) }\end{array}$ & Mangrove species \\
\hline Atrato River Delta & Fringing & 3846 & 17.1 & 7.8 & 26.2 & 494 & $\mathrm{Rm}, \mathrm{Lr}, \mathrm{Ag}, \mathrm{Pr}$ \\
\hline Puerto Cesar-Punta Coquito & Fringing & 406 & 9.0 & 7.6 & 12.5 & 464 & Rm, Lr, Ag, Pr \\
\hline \multirow{2}{*}{ Punta Yarumal-Punta Las Vacas } & Fringing & 48 & 5.6 & 6.7 & 32.2 & 220 & $\mathrm{Rm}, \mathrm{Lr}, \mathrm{Ag}$ \\
\hline & Basin & 98 & 5.4 & 7.3 & 20.7 & 182 & $\mathrm{Rm}, \mathrm{Lr}, \mathrm{Ag}$ \\
\hline \multirow{3}{*}{ Rionegro Cove } & Fringing & 53 & 10.4 & 13.0 & 11.5 & 324 & $\mathrm{Rm}, \mathrm{Lr}$ \\
\hline & Riverine & 241 & 15.3 & 9.8 & 13.0 & 309 & $\mathrm{Rm}, \mathrm{Lr}, \mathrm{Ag}$ \\
\hline & Early succession & 50 & 19.2 & 9.5 & 6.0 & 129 & $\mathrm{Rm}$ \\
\hline
\end{tabular}

Yarumal-Las Vacas) exhibited fewer trees than expected in the DBH $7-17 \mathrm{~cm}$ range, and individuals $>40 \mathrm{~cm}$ were lacking (Figure 2). This forest also exhibited the lowest mean tree diameter and mean density (Table 1 ), a pattern promoted by selective logging of $R$. mangle and A. germinans, the species with greater importance value (IVI) in the Eastern Coast (Figure 3). Selective logging and mangrove reclamation indirectly increased the IVI of $L$. racemosa in suburban basin mangroves (see discussion in Section 5), in contrast to the observed in isolated mangroves (Figure 3).

In the Urabá Gulf, selective logging has been traditionally conducted by fishermen for direct households and smallscale commerce in Turbo (Figure 4). R. mangle is predominantly exploited for poles, but their commerce is poorly attractive [42], as evidenced by the piles commonly abandoned in informal markets, streets, or even in the field. On the other hand, charcoal production is a common practice, but it is time consuming and poorly rewarded, because a sack is sold at 4 USD (COP 8,000), although it requires logging and burning 20 trees (Figure 4). A. germinans trees are not commonly marketed, but they are logged on demand for construction pilings and planks (Figure 4). In addition to selective logging, basin mangroves are cleared for understory cattle ranching and for establishing pastures (Figure 4). Such practices in mangroves and coastal-plain forests are responsible for high annual deforestation rates (1.9\% [51]) exceeding those observed in Colombian terrestrial forest hotspots [52].

Contrary to the observed in many places, mangroves in the Urabá Gulf are exploited for a few uses, and, in general, they are disregarded as a source of goods and services. Uses and sizes for a given mangrove species may differ from one place to another even within a single region in many parts of the world [29, 32]. Extraction of poles from $R$. mangle trees with $\mathrm{DBH}<15 \mathrm{~cm}$ has also been reported from Venezuela [53]. Recently, as overexploitation of $R$. mangle has reduced the available $\mathrm{DBH}$, loggers are extracting $L$. racemosa. It is in contrast with the observed in some areas of Mexico, where $L$. racemosa is preferably exploited for woody products over A. germinans and $R$. mangle, species that are mostly used for nonwoody products (i.e., medicine and leather dying), while no wood is burned for charcoal production [29]. Therefore, it is important to understand the objectives of selective logging to explain patterns in terms of sizes exploited, level of exploitation, degree of mechanization, and spatial distribution as influenced by access from towns and villages $[6,25,32]$. Although ethnoecological studies have been instrumental for reconstruction of past uses of mangroves and impacts derived $[8,46,47,54]$, more studies are urged for the Neotropics because a few case studies exist (e.g., Mexico: [55], Venezuela: [53]) and most of the examples concentrate in the Indopacific [6].

\section{Estimated Biomass and Carbon Reservoirs as Influenced by Deforestation}

Mangrove biomass was traditionally appreciated as a major ecosystem good, but its importance in the coastal carbon budget has been recently highlighted [10, 11, 49, 56, 57]. It is intuitively accepted that deforestation depletes aboveground carbon reservoirs. However, as stated by Bouillon et al. [10], "...information (if any) about carbon losses associated to clear-falling are [sic] difficult to obtain since this activity is illegal in most countries; actual records of total biomass extracted to use mangrove area for other purposes (e.g., roads, urban development) is also rare making it difficult to determine this component in global estimates of carbon sequestration." In order to account for the impact of selective logging on biomass and carbon reservoirs in the vicinity of the Turbo municipality, we combined forest structure data [39] and published allometric equations [58, 59]. Fringing mangroves at the Atrato River Delta stored the greatest amount of aboveground carbon $(89.3 \mathrm{Mg} \mathrm{C} / \mathrm{ha})$ in comparison to the Eastern Coast mangroves (Table 2). The selective logging in the suburban mangroves in the vicinity of Turbo $(48.3 \mathrm{MgC} / \mathrm{ha})$ did not significantly reduce total C storage compared to other locations. Nonetheless, the low total aboveground $\mathrm{C}$ reservoir in basin mangroves in Punta Las Vacas-Punta Yarumal $(17.5 \mathrm{MgC} / \mathrm{ha})$ and the relatively high proportion stored in L. racemosa $(5.2 \mathrm{MgC} / \mathrm{ha}$ $=30 \%$ of total reservoir) may reflect a strong pressure by selective logging and pasture expansion. Regardless of the mangrove location, $R$. mangle contributed most of the carbon reservoir but in the suburban basin mangroves $L$. racemosa contributed a similar amount (Table 2). Therefore, selective logging seems to unbalance carbon allocation among species rather than promoting a net loss in total reservoir. In contrast to selective logging, a major impact is 


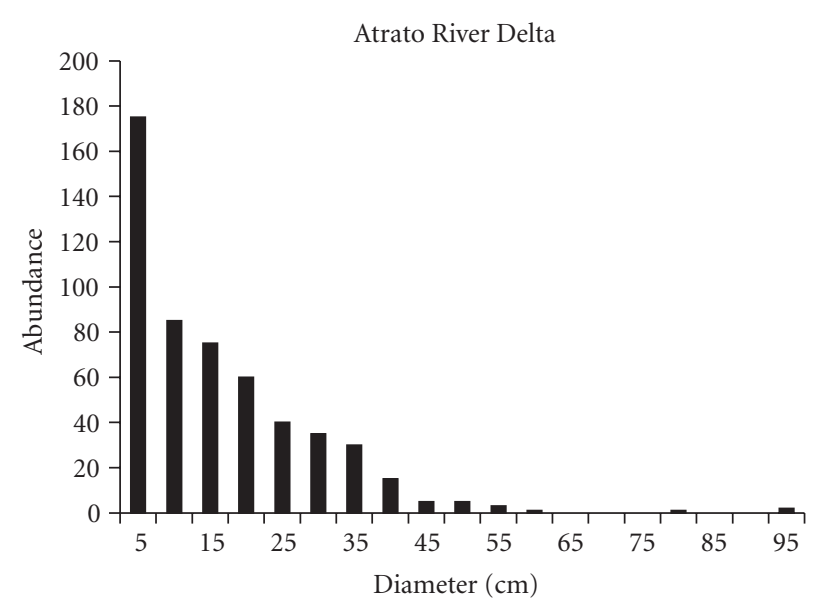

Fringing

(a)

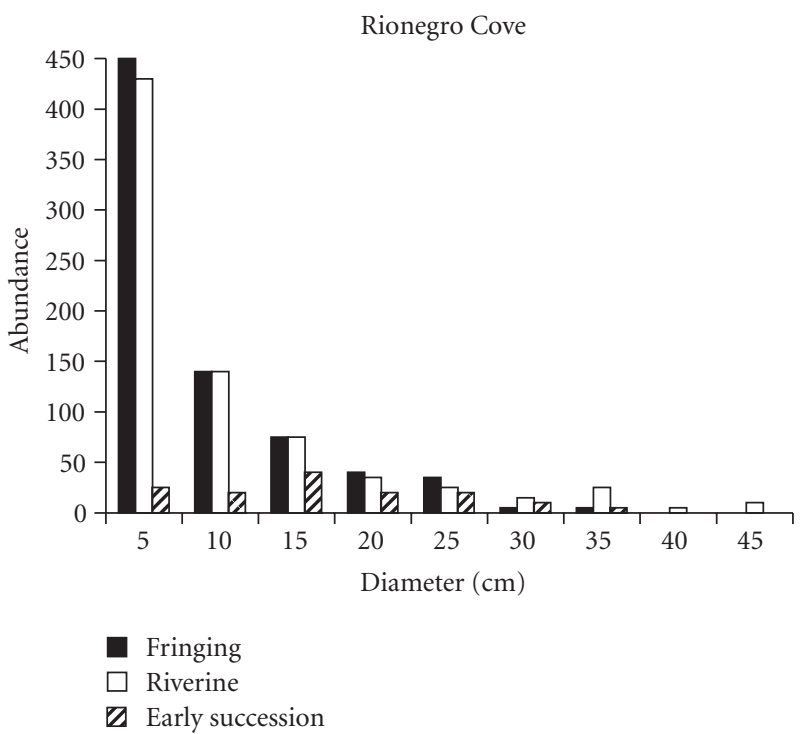

(c)

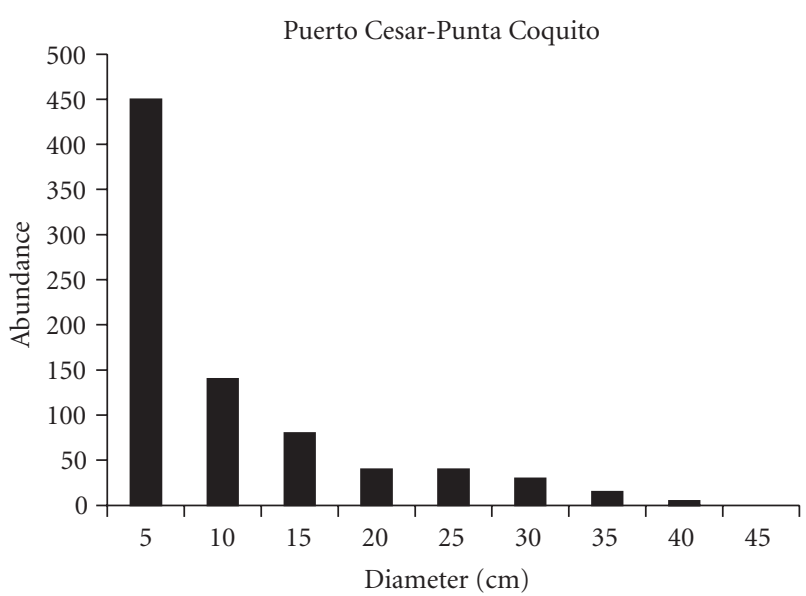

Fringing

(b)

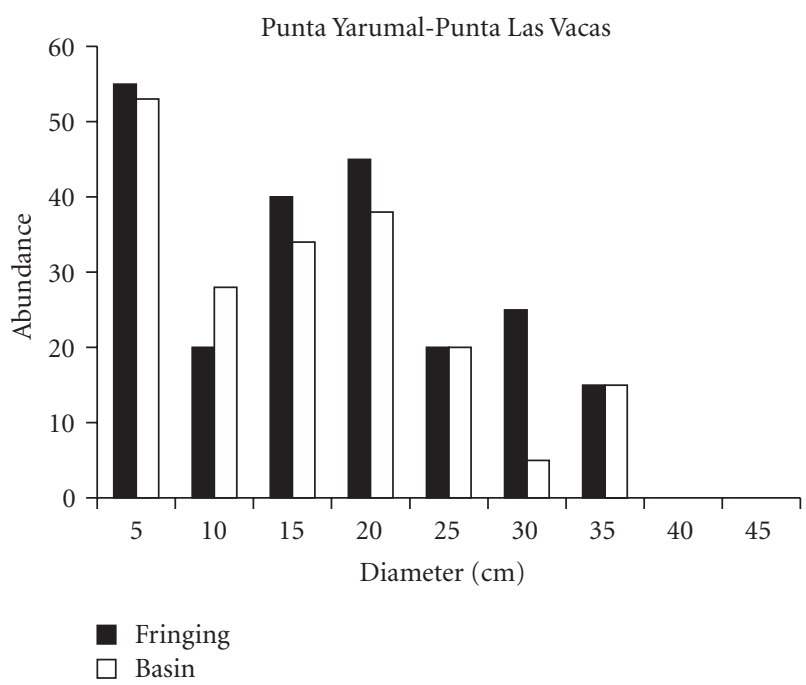

(d)

FIGURE 2: Distribution of mangrove tree diameter at breast height in four locations and four mangrove physiographic types (modified from Urrego et al. [39]). Sampling effort (500 $\mathrm{m}^{2}$ circular plots): Atrato River Delta $(n=25)$, Rionegro Cove $(n=30)$, Puerto Cesar-Punta Coquito $(n=10)$, and Punta Yarumal-Punta Las Vacas $(n=19)$. Note that total abundance is independent of sampling effort.

predicted from mangrove conversion to pasture as the entire above-ground reservoir is translocated to the ground as dead wood, in situ decomposed, and gradually washed away or emitted to the atmosphere [60].

Observed above-ground carbon reservoirs in the Urabá Gulf are within the range observed in the Tropics [10, 11, 49, $56,57]$. Compared to worldwide above-ground biomass data (as a proxy of carbon storage), mangroves in the Atrato River delta represent a significantly high reservoir, but Eastern Coast mangroves lay below the average (Tables 2 and 3; $[48,49])$. Therefore, conservation efforts should prevent clearing mangroves in the Atrato River delta in order to avoid releasing significant amounts of carbon to the atmosphere and to the ocean, thus negatively impacting the Gulf's budget. Smaller reservoirs may be locally important but seem to contribute little to the Gulf's total budget.

\section{Selective Logging as a Driver of Species Introgressions and Extinctions}

Clearing mangrove areas due to natural disturbances such as hurricanes has resulted in introgressions by fast-growing mangrove and nonmangrove species [61-65], and it is likely that selective logging and clear cutting may produce similar outcomes [46]. Moreover, the codominance of secondary mangrove species or antagonistic distributions can be indicators of cryptic ecological degradation (Dahdouh-Guebas et al. [46]). In the Urabá Gulf, we recently documented 


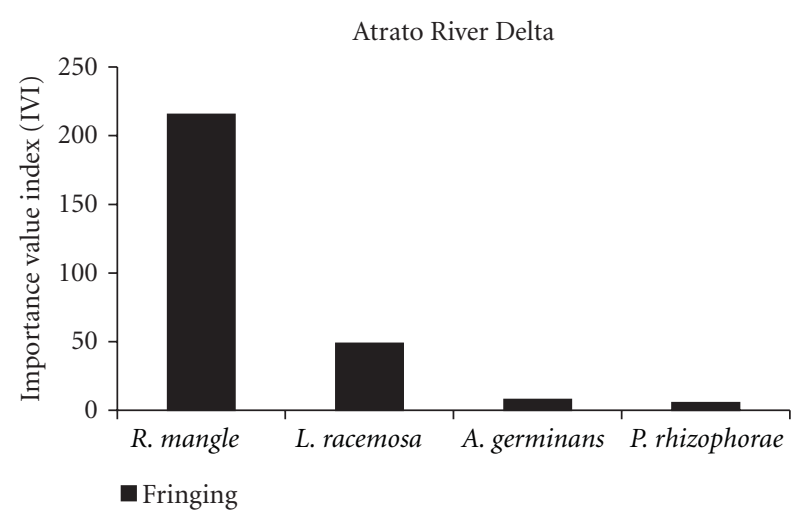

(a)

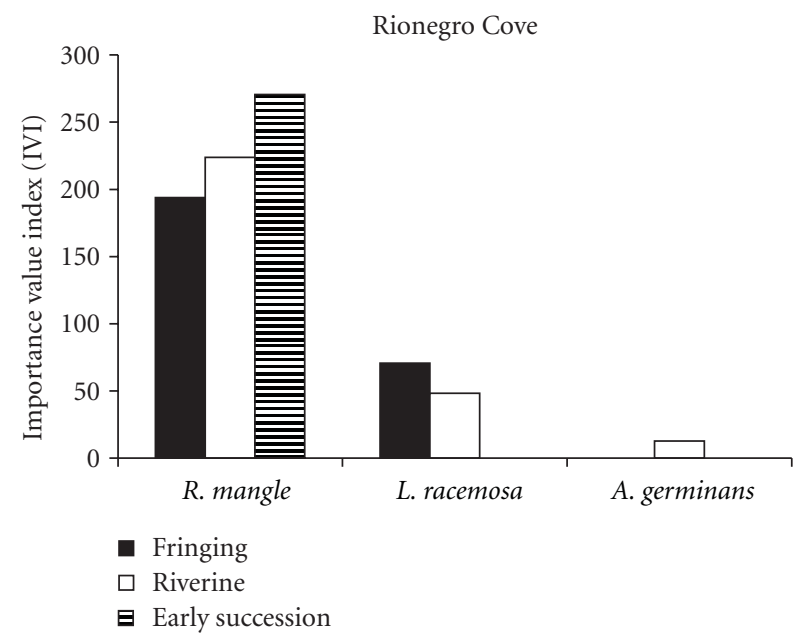

(c)

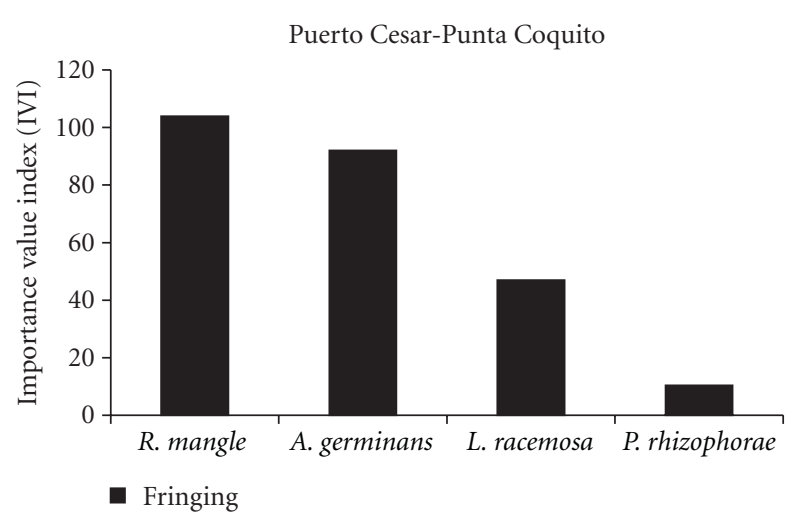

(b)

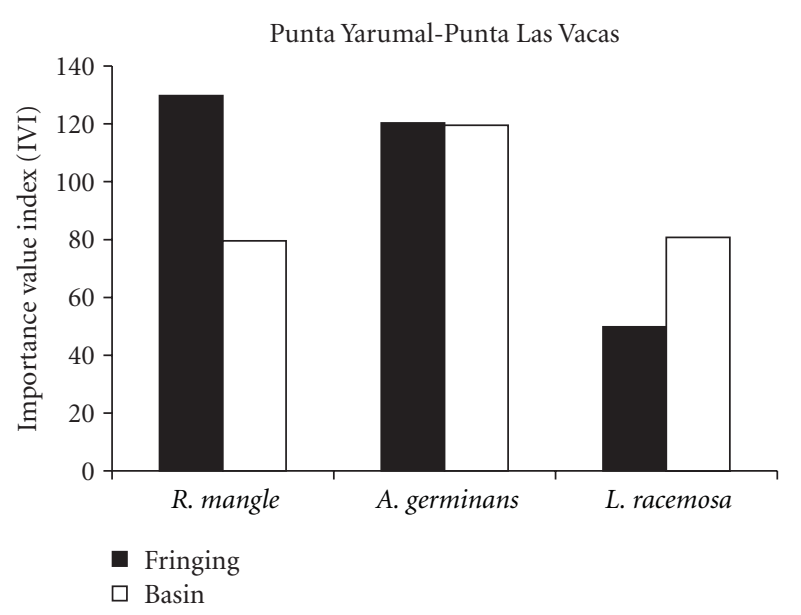

(d)

FIgURE 3: Importance value index (IVI) for mangrove species in four locations and four mangrove physiographic types (modified from Urrego et al. [39]).

that the IVI of $R$. mangle and $L$. racemosa were inversely correlated (Figure 5), because selective logging upon the first promoted overgrowth of latter (Figure $4(\mathrm{k})$ ), otherwise a secondary species, thus supporting the hypothesis of cryptic degradation. A similar proliferation of $L$. racemosa was observed in Panamian suburban mangroves as a consequence of reclamation [28]. No correlation was observed between the selective logging of $A$. germinans and the IVI of $L$. racemosa in basin mangroves, contrary to the observed in Belizean [64] and Puerto Rican [66] mangroves. In the surroundings of Turbo City (Punta Las Vacas), the mangrove fern Acrostichum aureum also invaded extensively cleared fringing mangroves (Figure 4(1)), and it has become a major barrier for natural recovery, as observed elsewhere $[8,25,46$, 67]. In other areas such as Punta Yarumal where mangrove trees have been selectively logged, $A$. aureum formed clumps in the understory. It is known that this fern proliferates in compacted, saline, and alkaline soils after mangrove clear cutting or hurricane-induced mass mortality [64, 68]. A recent study in Cispatá Lagoon System (Caribbean coast of Colombia) agreed that the high proportion of Laguncularia pollen may indicate the prevalence of anthropogenic disturbances on mangrove stands otherwise dominated by Rhizophora or Avicennia [69]. Nonetheless, Laguncularia pollen and Acrostichum spore records underscore the prevalence of human and natural disturbances in Caribbean mangroves, because pollen and spores are widespread distributed by water and air [70]. Conversely, A. aureum was also reported naturally occurring as an understory plant in A. germinans stands in La Mancha (Gulf of Mexico [71]. Interestingly, both $L$. racemosa and A. aureum, otherwise mangrove intrograders, also coexisted naturally with the swamp bloodwood Pterocarpus officinalis, and other two mangrove species in coastal forests developed in very low salinities in the southern part of the Urabá Gulf (e.g., Punta Coquito-Puerto Cesar). The association Pterocarpus-Acrostichum-Laguncularia has been well documented in Puerto Rico [66, 67].

The basin mangrove physiognomy and the dominant species (A. germinans) are also threatened, because, in contrast to the rest of the Caribbean, only small patches exist naturally at the Eastern Coast of the Urabá Gulf. Along this coast, entire basin mangroves have been converted to 


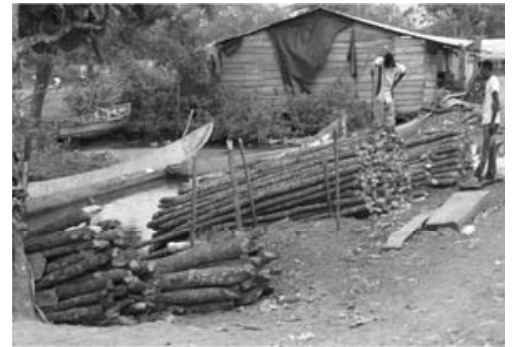

(a)

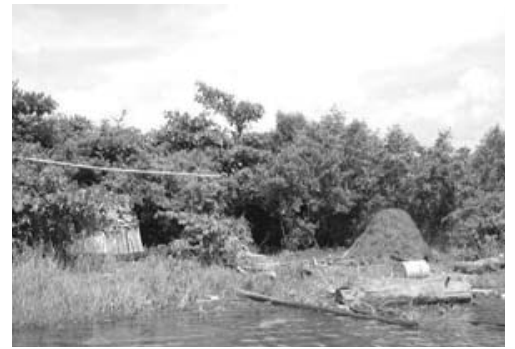

(d)

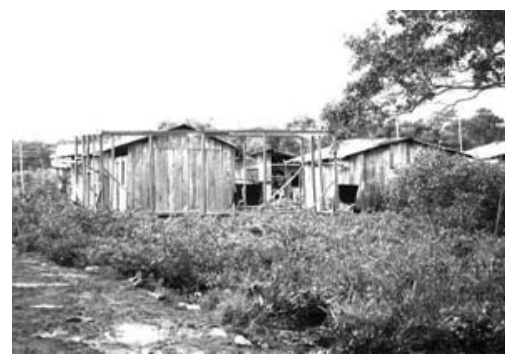

(g)

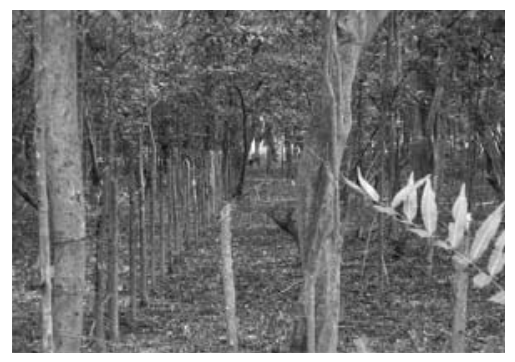

(j)

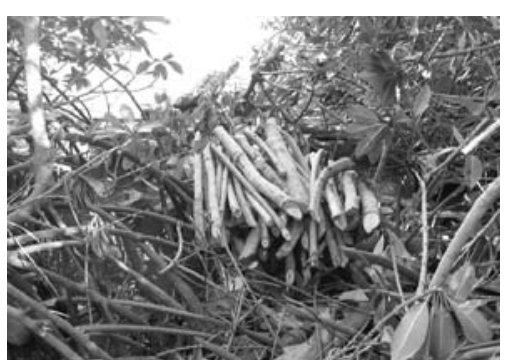

(b)

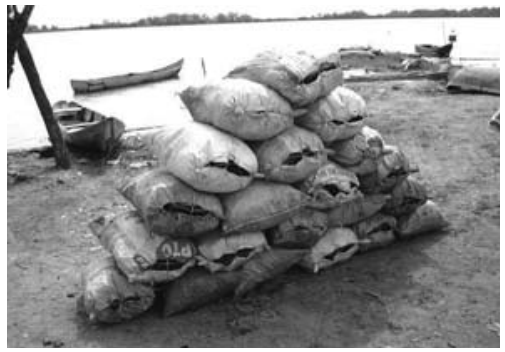

(e)

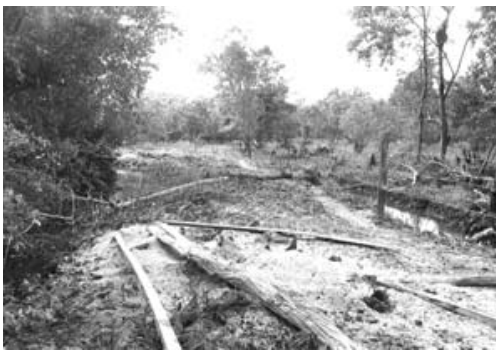

(h)

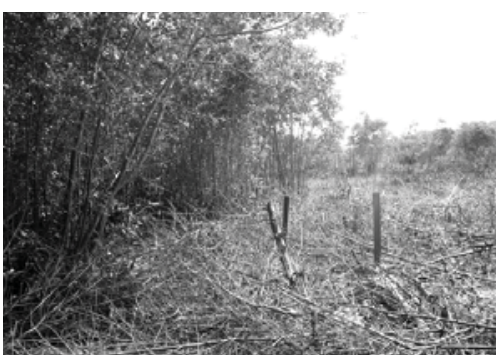

(k)

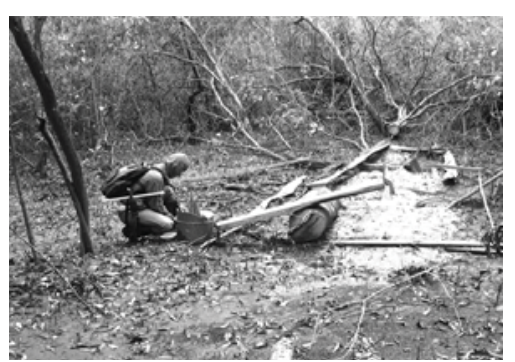

(c)

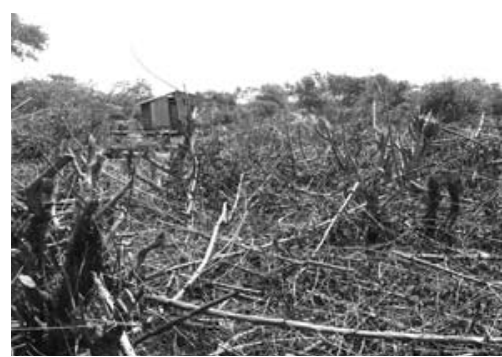

(f)

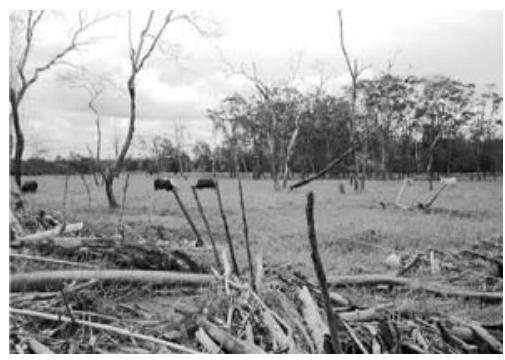

(i)

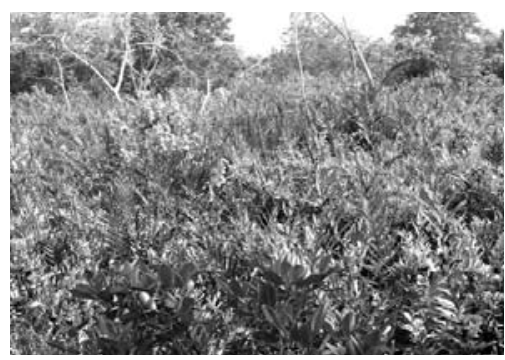

(1)

FIGURE 4: Impacts of selective logging and mangrove reclamation in the Urabá Gulf. Exploitation of mangrove wood (a-e). Mangrove reclamation for rural low-density housing $(\mathrm{f}-\mathrm{g})$. Mangrove conversion to pastures $(\mathrm{h}-\mathrm{j})$. Examples of cryptic ecological degradation $(\mathrm{k}-$ 1). Extraction of red mangrove (R. mangle) poles (a-b) and planks from a large black mangrove (A. germinans). Artisan ovens (d) for burning mangrove charcoal. Each sack of charcoal required felling 10-20 trees; this pile nearly exploited 200 trees, equaling one hectare from Punta Yarumal (e). Recent mangrove reclamation for rural settlement, noting the deadwood left in place (f). Reclaimed periurban mangrove showing abundant resprouting $(\mathrm{g})$. Examples of mangrove clear cutting and digging desiccation drainages $(\mathrm{H})$ for establishing active pastures (i); note the few standing black mangrove trees. Black mangrove stand with a cleared understory for cattle ranching (note the fencing) (j). White mangrove (Laguncularia racemosa) resprouting in a cleared area (k). Introgression by Acrostichum aureum (l). Photos: E. A. Estrada and A. Taborda.

pastures, thus locally decimating mangrove patches along with the dominant $A$. germinans (Figures 4(i) and 4(j)), similarly to the reported patch shrinking and species extinctions in periurban mangroves in Mombasa (Kenya) [47]. Finally, selective logging might be responsible for local extinction of the vulnerable mangrove species Pelliciera rhizophorae (Figure 3: Puerto Cesar-Punta Coquito and Atrato River
Delta; but recently recorded in Punta Las Vacas). P. rhizophorae is found in the Caribbean only in a few locations in Colombia, contrary to its codominance along the Pacific coast of Central and South America [72-74].

Extinctions and invasions in species-poor mangrove in the Neotropics are expected to bring notorious ecosystemwide effects [75]. In addition, since specific ecosystem 


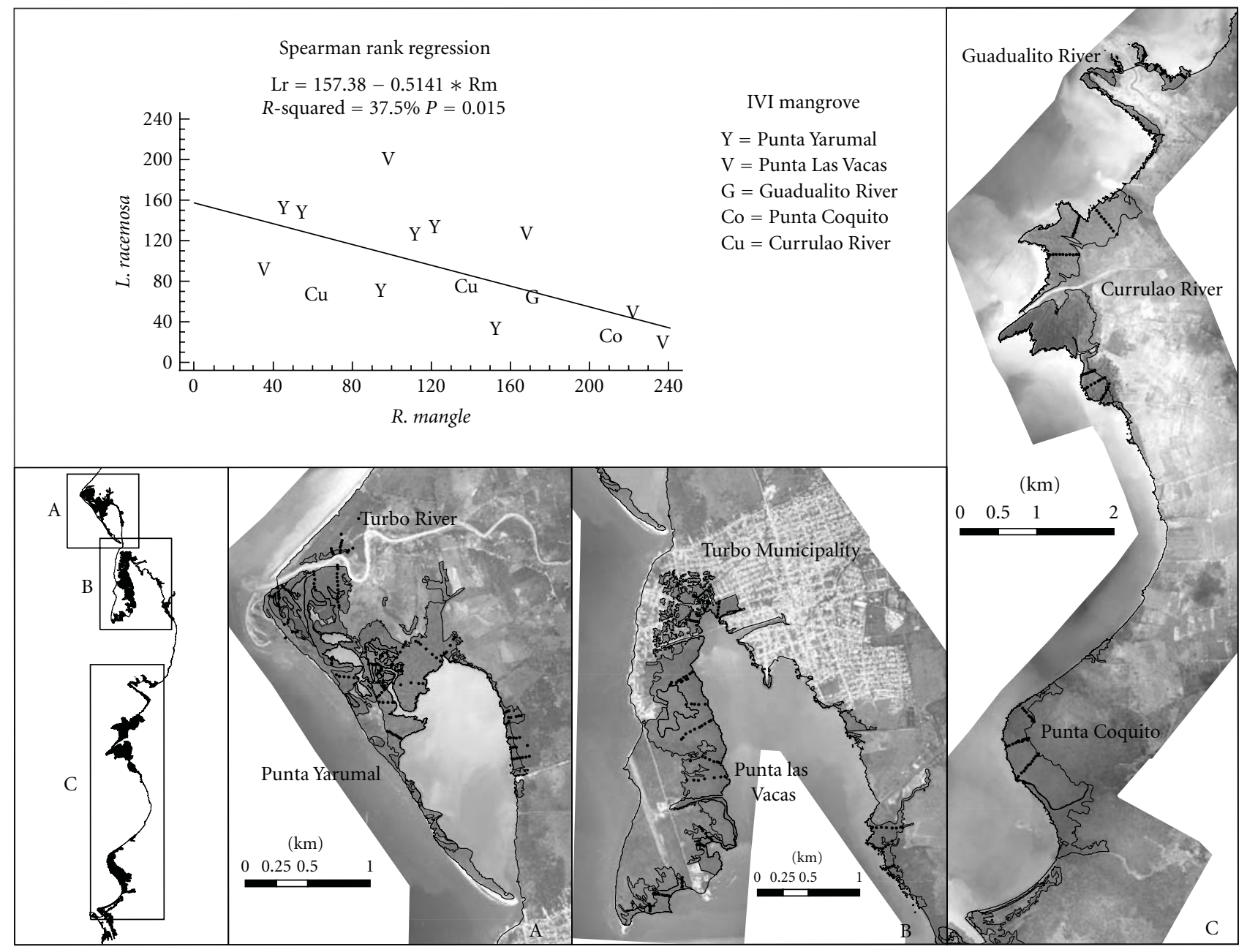

- Sampling points

Figure 5: Negative regression between $R$. mangle and L. racemosa importance value index (IVI) in the Eastern Coast of the Urabá Gulf. Sampling point-centered quadrats are shown for five mangrove locations (outlining). Data from a master's thesis in progress by E. A. Estrada.

services are provided by particular mangrove species and physiognomies [7], the observed patterns and rates of selective logging and reclamation in the Urabá Gulf will probably produce negative feedbacks in human populations deriving direct and indirect services from mangroves.

\section{Impacts of Selective Logging and Mangrove Reclamation on Benthic Fauna}

Deforestation negatively affects benthic communities; however, there are a few accounts on the direct and indirect impacts and mechanisms. At an ecoregional scale, we observed that Littorinopsis angulifera (Gastropoda: Littorinidae) and Neritina virginea (Gastropoda: Neritidae), two iconic species in Caribbean mangroves, lacked adults or individuals at all, respectively, in small mangrove patches seemly shrinking due to deforestation and coastal erosion, along the northern and eastern coasts of the Urabá Gulf [76]. At a landscape scale, we also reported that both selective logging and mangrove reclamation were responsible for reduced density in N. virginea (as well as in Melampus coffeus-Ellobiidae, a typical mangrove pulmonate gastropod) in Punta Yarumal in the vicinity of Turbo [40]. Selective logging promoted canopy gaps, alteration of forest structure, and sediment trampling, while mangrove conversion to pastures promoted increased soil temperature and desiccation and eliminated hard substrates (trees, prop roots, seedlings, and pneumatophores) (Figure 4, Figures 6(a), and 6(d)). Given the clumped distribution of N. virginea, the percent of sampling quadrats with snails was a reliable indicator of impact due to selective logging and of "edge effect" in the mangrove-pasture transition (Figures 6(b) and 6(c); [41]). Such reductions seemed to be primarily mediated by changes in surface sediment properties (e.g., $\mathrm{pH}$, temperature, organic matter content) and microhabitat complexity (trees, prop roots, and pneumatophores). Selective logging may indirectly affect climbing gastropods (i.e., L. angulifera and M. coffeus) by eliminating their preferred habitats because they crawl on the trees during flooding tides $[40,77]$. In 
TABLE 2: Aboveground (area-weighed) carbon and biomass in mangroves in the Urabá Gulf. Computed from structure data from Urrego et al. [39] and allometric equations from [46, 47].

\begin{tabular}{|c|c|c|c|c|c|}
\hline Location & Mangrove type & Mangrove species & $\begin{array}{c}\text { Mean relative } \\
\text { abundance }(\%)\end{array}$ & $\begin{array}{l}\text { Above-ground carbon } \\
\text { (Mg C/ha) }\end{array}$ & $\begin{array}{c}\text { Above-ground } \\
\text { biomass }(\mathrm{Mg} / \mathrm{ha})\end{array}$ \\
\hline \multirow{4}{*}{ Atrato River Delta } & \multirow{4}{*}{ Fringing } & R. mangle & 83.0 & 83.7 & 167.4 \\
\hline & & A. germinans & 1.0 & 0.7 & 1.3 \\
\hline & & L. racemosa & 9.5 & 5.0 & 9.9 \\
\hline & & Total & & 89.3 & 178.7 \\
\hline \multirow{4}{*}{ Puerto Cesar-Punta Coquito } & \multirow{4}{*}{ Fringing } & R. mangle & 43.3 & 13.1 & 26.2 \\
\hline & & A. germinans & 21.6 & 4.3 & 8.6 \\
\hline & & L. racemosa & 19.9 & 3.5 & 6.9 \\
\hline & & Total & & 20.8 & 41.7 \\
\hline \multirow{8}{*}{ Punta Yarumal-Punta Las Vacas } & \multirow{4}{*}{ Fringing } & R. mangle & 76.5 & 25.9 & 51.8 \\
\hline & & A. germinans & 12.9 & 2.9 & 5.8 \\
\hline & & L. racemosa & 10.6 & 2.0 & 4.0 \\
\hline & & Total & & 30.8 & 61.6 \\
\hline & \multirow{4}{*}{ Basin } & R. mangle & 43.5 & 10.1 & 20.2 \\
\hline & & A. germinans & 14.7 & 2.3 & 4.5 \\
\hline & & L. racemosa & 39.5 & 5.2 & 10.4 \\
\hline & & Total & & 17.5 & 35.1 \\
\hline \multirow{10}{*}{ Rionegro Cove } & \multirow{4}{*}{ Fringing } & R. mangle & 67.2 & 8.9 & 17.8 \\
\hline & & A. germinans & 0.0 & 0.0 & 0.0 \\
\hline & & L. racemosa & 21.3 & 1.7 & 3.4 \\
\hline & & Total & & 10.6 & 21.3 \\
\hline & \multirow{4}{*}{ Riverine } & R. mangle & 86.4 & 20.3 & 40.6 \\
\hline & & A. germinans & 3.4 & 0.5 & 1.1 \\
\hline & & L. racemosa & 8.6 & 1.1 & 2.2 \\
\hline & & Total & & 21.9 & 43.9 \\
\hline & \multirow{2}{*}{ Early succession } & R. mangle & 91.4 & 15.4 & 30.9 \\
\hline & & Total & & 15.4 & 30.9 \\
\hline
\end{tabular}

contrast, the bottom-dwelling and numerically dominant gastropod $N$. virginea moves extensively along the intertidal zone covered by mangroves due to their diadromous behavior $[40,78,79]$, and, therefore, selective logging and clearing promote population fragmentation because they cannot venture out of the flooded areas, particularly into the newly established pastures $[40,41]$. We hypothesized that, as a consequence of N. virginea decline, sediment bioturbation and mangrove litter decomposition would be reduced. This species is a grazer and a facultative detritivore, and given its high density and biomass (range: $16-100 \mathrm{ind} . / \mathrm{m}^{2} ; 11.9$ $\left.74.3 \mathrm{~g} / \mathrm{m}^{2} ;[40]\right)$, it seems to be responsible for the rapid processing of black mangrove (A. germinans) leaflitter (A. Taborda and J. F. Blanco in preparation). Gastropods in the Caribbean and elsewhere have been pointed as key detritivores and sediment grazers, even outweighing the role of crabs [80-82].

Available assessments on the impacts of mangrove deforestation on benthos report that vegetation provides support and physical habitat that may reduce predation and desiccation (Asia: [83, 84]; Africa: [85, 86]; Australia: [87]). For instance, clearing pneumatophores in small-scale deforestations for building walkways and trails was correlated with a decline in density and species richness in the entire community, particularly on gastropods [87]. In addition, community and population metrics, otherwise uncorrelated with physicochemical variables under natural conditions [84], became significantly explained by temperature and $\mathrm{pH}$ in deforested mangroves [86].

\section{Conclusions}

Selective logging and conversion to pastures have negative effects in forest structure and species composition, aboveground biomass and carbon reservoir, invasiveness, and benthic fauna in the Urabá Gulf mangroves. Mangroves settled in the Eastern Coast have been decimated, contrary to the observed in Atrato River Delta and the Rionegro Cove. In terms of forest structure, selective logging has decimated trees in the DBH range $7-17 \mathrm{~cm}$ due to the extraction of $R$. 
(m)

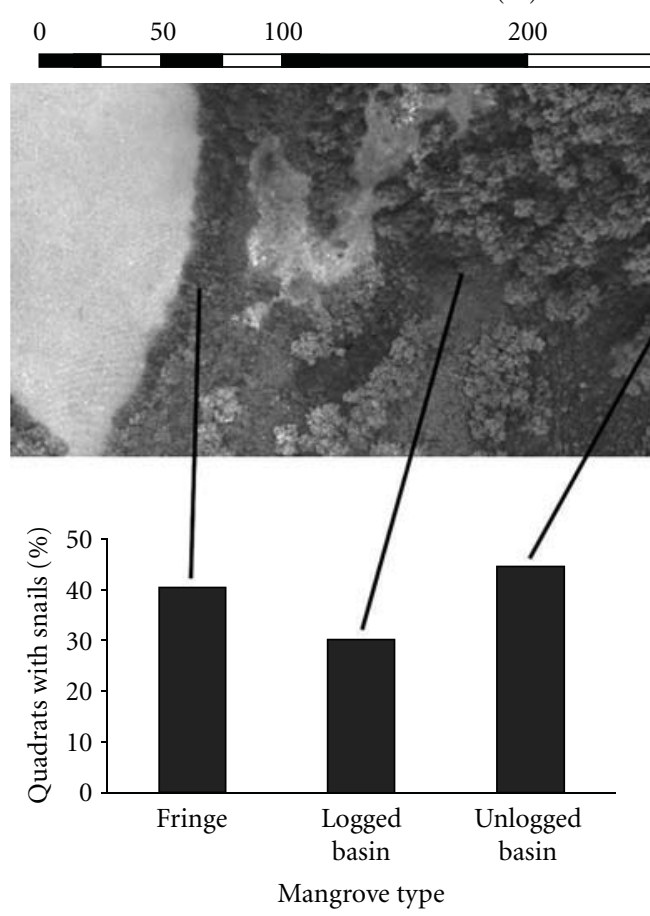

(b)

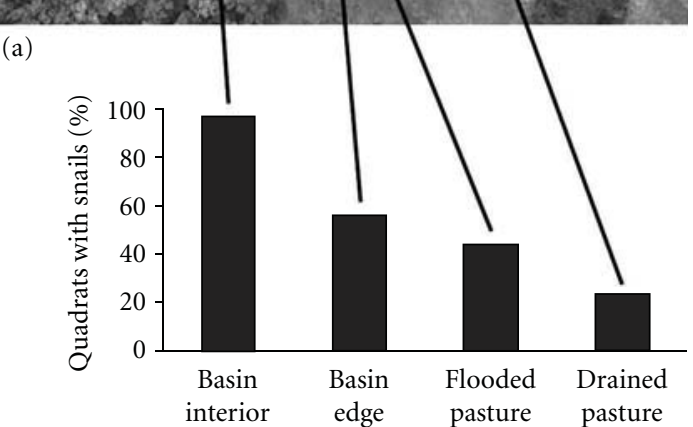

Position relative to the deforestation front

(c)

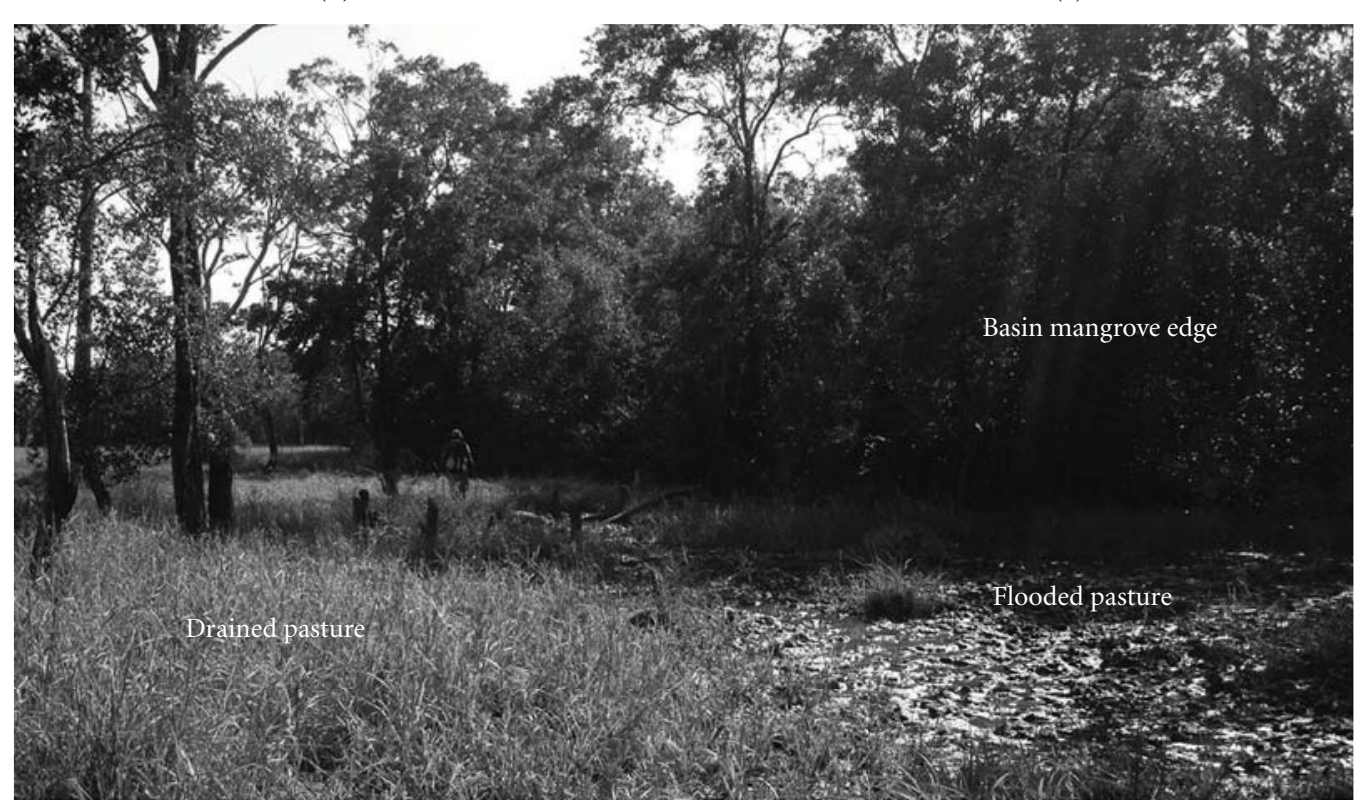

(d)

FIgURE 6: Occurrence of dominant gastropods (Neritina virginea) along a mangrove-pasture transition in Punta Yarumal (Turbo River Delta). (a) Gastropod occurrence (\%) relative to mangrove type and selective logging (b) and to mangrove-pasture edge (c, d). Data from $[40,41]$.

mangle poles. A lack of A. germinans trees of DBH $>40 \mathrm{~cm}$ evidenced the extraction for planks and pilings. Selective logging increased the IVI of $L$. racemosa, an opportunistic species, invading canopy gaps, and recently cleared mangroves. In addition to selective logging, clear cutting of basin-type mangroves is a common practice for establishing pastures, thus extracting most of tree biomass and leaving a few standing A. germinans trees. Selective logging seems to reduce total mangrove biomass and carbon, particularly in basin mangroves, but more importantly it is clearly altering allocation among species by reducing the storage in $R$. mangle and A. germinans and increasing the L. racemosa 
TABLE 3: Above-ground biomass for mangrove forests worldwide.

\begin{tabular}{lc}
\hline Location & Above-ground biomass $(\mathrm{Mg} / \mathrm{ha})$ \\
\hline Neotropics ${ }^{1}$ & \\
Dominican Republic & 195.4 \\
Dominican Republic & 349.4 \\
Florida & 56.0 \\
Florida & 72.0 \\
Florida & 22.3 \\
Florida & 56.0 \\
Guadeloupe & 47.0 \\
Guadeloupe & 56.0 \\
Guadeloupe & 99.0 \\
Hawaii & 279.0 \\
Mexico & 135.0 \\
Mexico & 120.0 \\
Puerto Rico & 62.9 \\
\hline Neotropics Mean & 119.2 \\
\hline Old World tropics ${ }^{1}$ & \\
Indonesia & 93.7 \\
Malaysia & 409.0 \\
Malaysia & 216.4 \\
Sri Lanka & 71.0 \\
Sri Lanka & 71.0 \\
Thailand & 158.0 \\
Western Australia & 246.7 \\
Western Australia & 45.8 \\
Australia & 711.0 \\
\hline Old World Mean & 224.7 \\
\hline Pacific Islands ${ }^{2}$ & \\
Ruunuw. Yap. FSM & 225.0 \\
Pacific Islands Mean &
\end{tabular}

${ }^{1}$ Data from Sherman et al. 2003 [48].

${ }^{2}$ Data from Kauffman et al. 2011 [49].

reservoir. Selective logging of $R$. mangle and clear-cutting of basin mangroves promoted introgressions by $L$. racemosa and the mangrove fern $A$. aureum in periurban sites, and they were a clear sign of cryptic ecological degradation. It is suspected that selective logging may also drive rare species such as $P$. rhizophorae to local extinction. Finally, selective logging and mangrove conversion to pastures were responsible for density declines of dominant gastropods (N. virginea) in mangrove canopy gaps and edges, and it is hypothesized that cascading effects may consequently occur in sediment bioturbation and leaflitter processing. Employing an interdisciplinary approach proved to be useful to demonstrate that basin mangroves are the most threatened physiognomy by deforestation due to their proximity to expanding pastures and villages. In conclusion, selective (noncommercial and unplanned) logging in Urabá Gulf mangroves, particularly in the Eastern Coast, already shows signs of unsustainability, and it is worsened by the rapid mangrove conversion to pastures.

\section{Acknowledgments}

Funding was provided by the Antioquia State Planning Secretariat, Universidad de Antioquia, Universidad Nacional and EAFIT consortium named "Expedición Estuarina, golfo de Urabá, Fase 1". Additional funds came from a Universidad Nacional-DIME grant (code 20101007166) to L. UrregoGiraldo, and a Universidad de Antioquia-CODI grant ("Mangrove fragmentation in Urabá Gulf") to E. Estrada and J. Blanco. Comments from six anonymous reviews greatly improved paper. ELICE contribution No. 6.

\section{References}

[1] D. M. Alongi, "Present state and future of the world's mangrove forests," Environmental Conservation, vol. 29, no. 3, pp. 331-349, 2002.

[2] E. J. Farnsworth and A. M. Ellison, "The global conservation status of mangroves," Ambio, vol. 26, no. 6, pp. 328-334, 1997.

[3] I. Valiela, J. L. Bowen, and J. K. York, "Mangrove forests: one of the world's threatened major tropical environments," BioScience, vol. 51, no. 10, pp. 807-815, 2001.

[4] Millennium Ecosystem Assessment (MEA), Ecosystems and Human Well-Being: Scenarios, Island Press, Washington, DC, USA, 2005.

[5] S. Rist and F. Dahdouh-Guebas, "Ethnosciences-a step towards the integration of scientific and indigenous forms of knowledge in the management of natural resources for the future," Environment, Development and Sustainability, vol. 8, no. 4, pp. 467-493, 2006.

[6] B. B. Walters, P. Rönnbäck, J. M. Kovacs et al., "Ethnobiology, socio-economics and management of mangrove forests: a review," Aquatic Botany, vol. 89, no. 2, pp. 220-236, 2008.

[7] K. C. Ewel, R. R. Twilley, and J. E. Ong, "Different kinds of mangrove forests provide different goods and services," Global Ecology and Biogeography Letters, vol. 7, no. 1, pp. 83-94, 1998.

[8] F. Dahdouh-Guebas, E. Van Hiel, J. C.-W. Chan, L. P. Jayatissa, and N. Koedam, "Qualitative distinction of congeneric and introgressive mangrove species in mixed patchy forest assemblages using high spatial resolution remotely sensed imagery (IKONOS)," Systematics and Biodiversity, vol. 2, no. 2, pp. 113119, 2005.

[9] F. Dahdouh-Guebas and N. Koedam, "Coastal vegetation and the Asian tsunami," Science, vol. 311, no. 5757, pp. 37-38, 2006.

[10] S. Bouillon, V. Rivera-Monroy, R. R. Twilley, and J. G. Kairo, "Mangrove," in The Management of Natural Coastal Carbon Sinks, D. d'A. Laffoley and G. Grimsditch, Eds., pp. 13-20, IUCN, Gland, Switzerland, 2009.

[11] D. C. Donato, J. B. Kauffman, D. Murdiyarso, S. Kurnianto, M. Stidham, and M. Kanninen, "Mangroves among the most carbon-rich forests in the tropics," Nature Geoscience, vol. 4, no. 5, pp. 293-297, 2011.

[12] N. C. Duke, J.-O. Meynecke, S. Dittmann et al., "A world without mangroves?" Science, vol. 317 , no. 5834, pp. 41-42, 2007.

[13] F.A.O. (Food and Agriculture Organization of the United Nations), “The world's mangroves 1980-2005," FAO Forestry Paper 153, FAO, Rome, Italy, 2007.

[14] C. Kuenzer, A. Bluemel, S. Gebhardt, T. V. Quoc, and S. Dech, "Review remote sensing of mangrove ecosystems: a review," Remote Sensing, vol. 3, pp. 878-928, 2011. 
[15] R. Álvarez-Léon, "Mangrove ecosystems of Colombia," in Conservation and Sustainable Utilization of Mangrove Forests in Latin America and Africa Regions, L. D. Lacerda, Ed., pp. 75 114, Society for Mangrove Ecosystems, Okinawa, Japan, 1993.

[16] R. Álvarez-León and J. Polanía, "Los manglares del Caribe colombiano: síntesis de su conocimiento," Revista de la Academia Colombiana de Ciencias Exactas, Físicas y Naturales, vol. 20, no. 78, pp. 447-464, 1996.

[17] H. Sánchez-Páez, R. Álvarez-León, F. Pinto-Nolla et al., "Diagnóstico y Zonificación Preliminar de los Manglares del Caribe de Colombia," Proyecto. PD 171/91 Rev.2 (F) Fase I. Conservación y Manejo Para el Uso Múltiple de los Manglares de Colombia, MinAmbiente/OIMT. Bogotá D.C., Colombia, 1997.

[18] H. Sánchez-Páez, R. Álvarez-León, O. A. Guevara-Mancera, A. Zamora-Guzmán, H. Rodríguez-Cruz, and H. E. BravoPazmiño, "Diagnóstico y Zonificación Preliminar de los Manglares del Pacífico de Colombia," Proyecto PD 171/91 Rev.2 (F) Fase I. Conservación y Manejo Para el Uso Múltiple de los Manglares de Colombia, MinAmbiente/OIMT. Bogotá D.C., Colombia, 1997.

[19] H. Sánchez-Páez, G. A. Ulloa-Delgado, and R. Álvarez-León, Eds., "Conservación y uso sostenible de los manglares del Caribe colombiano," Proyecto PD 171/91 Rev.2 (F) Fase II, Etapa I. Conservación y Manejo Para el Uso Múltiple de los Manglares de Colombia, MinAmbiente/ACOFORE/OIMT. Bogotá D.C., Colombia, 1998.

[20] H. Sánchez-Páez, G. A. Ulloa-Delgado, and R. Álvarez-León, Eds., "Hacia la recuperación de los manglares del Caribe de Colombia," Proyecto PD 171/91 Rev.2 (F) Fase II, Etapa II. Conservación y Manejo Para el Uso Múltiple de los Manglares de Colombia, MinAmbiente/ACOFORE/OIMT. Bogotá D.C., Colombia, 2000.

[21] R. Álvarez-León, "Los manglares de Colombia y la recuperación de sus áreas degradadas: revisión bibliográfica y nuevas experiencias," Madera Bosques, vol. 9, no. 1, pp. 3-25, 2003.

[22] M. Simard, V. H. Rivera-Monroy, J. Mancera-Pineda, E. Castañeda-Moya, and R. R. Twilley, "A systematic method for 3D mapping of mangrove forests based on Shuttle Radar Topography Mission elevation data, ICEsat/GLAS waveforms and field data: application to Ciénaga Grande de Santa Marta, Colombia," Remote Sensing of Environment, vol. 112, no. 5, pp. 2131-2144, 2008.

[23] A. M. Ellison and E. J. Farnsworth, "Anthropogenic disturbance of Caribbean mangrove ecosystems: past impacts, present trends, and future predictions," Biotropica, vol. 28, no. 4, pp. 549-565, 1996.

[24] M. Hirales-Cota, J. Espinoza-Avalos, B. Schmook, A. RuizLuna, and R. Ramos-Reyes, "Drivers of mangrove deforestation in Mahahual-Xcalak, Quintana Roo, Southeast Mexico," Ciencias Marinas, vol. 36, no. 2, pp. 147-159, 2010.

[25] F. Dahdouh-Guebas, A. Verheyden, W. De Genst, S. Hettiarachchi, and N. Koedam, "Four decade vegetation dynamics in Sri Lankan mangroves as detected from sequential aerial photography: a case study in Galle," Bulletin of Marine Science, vol. 67, no. 2, pp. 741-759, 2000.

[26] P. T. Obade, F. Dahdouh-Guebas, N. Koedan, R. De Wulf, and J. Tack, "GIS-based integration of interdisciplinary Ecological data to detect land-cover changes in creek mangroves at Gazi bay, Kenya," Western Indian Journal of Marine Sciences, vol. 3, no. 1, pp. 11-27, 2004.
[27] B. Satyanarayana, K. A. Mohamad, I. F. Idris, M. L. Husain, and F. Dahdouh-Guebas, "Assessment of mangrove vegetation based on remote sensing and ground-truth measurements at Tumpat, Kelantan Delta, East Coast of Peninsular Malaysia," International Journal of Remote Sensing, vol. 32, no. 6, pp. 1635-1650, 2011.

[28] S. L. Benfield, H. M. Guzman, and J. M. Mair, "Temporal mangrove dynamics in relation to coastal development in Pacific Panama," Journal of Environmental Management, vol. 76, no. 3, pp. 263-276, 2005.

[29] R. H. Cornejo, N. Koedam, A. R. Luna, M. Troell, and F. Dahdouh-Guebas, "Remote sensing and ethnobotanical assessment of the mangrove forest changes in the NavachisteSan Ignacio-Macapule Lagoon Complex, Sinaloa, Mexico," Ecology and Society, vol. 10, no. 1, article 16, 2005.

[30] F. Dahdouh-Guebas, C. Mathenge, J. G. Kairo, and N. Koedam, "Utilization of mangrove wood products around Mida Creek (Kenya) amongst subsistence and commercial users," Economic Botany, vol. 54, no. 4, pp. 513-527, 2000.

[31] F. Dahdouh-Guebas, J. G. Kairo, L. P. Jayatissa, S. Cannicci, and N. Koedam, "An ordination study to view vegetation structure dynamics in disturbed and undisturbed mangrove forests in Kenya and Sri Lanka," Plant Ecology, vol. 161, no. 1, pp. 123-135, 2002.

[32] A. N. Atheull, N. Din, S. N. Longonje, N. Koedam, and F. Dahdouh-Guebas, "Commercial activities and subsistence utilization of mangrove forests around the Wouri estuary and the Douala-Edea reserve (Csameroon)," Journal of Ethnobiology and Ethnomedicine, vol. 5, article 35, 2009.

[33] C. Tovilla-Hernández, G. E. de la Lanza, and D. E. OrihuelaBelmonte, "Impact of logging on a mangrove swamp in South Mexico: cost/benefit analysis," Revista de Biologia Tropical, vol. 49 , no. 2, pp. 571-580, 2001.

[34] F. Dahdouh-Guebas and N. Koedam, "Long-term retrospection on mangrove development using transdisciplinary approaches: a review," Aquatic Botany, vol. 89, no. 2, pp. 8092, 2008 .

[35] J. F. Blanco, M. Londoño, L. Urrego et al., "Expedición Estuarina, Golfo de Urabá, Fase 1; Expedición Antioquia 2013," Gobernación de Antioquia, Universidad de Antioquia, Universidad Nacional de Colombia, Universidad EAFIT (Final Report), Medellín, Colombia, 2010.

[36] J. F. Blanco, M. Londoño-Mesa, and L. Quan-Young, "The Urabá Gulf mangrove expedition of Colombia," ISME/GLOMIS Electronic Journal, vol. 9, no. 3, pp. 8-10, 2011.

[37] M. Coll, A. C. Fonseca, and J. Cortés, "El manglar y otras asociaciones vegetales de la laguna de Gandoca, Limón, Costa Rica," Revista de Biologia Tropical, vol. 49, supplement 2, pp. 321-329, 2001.

[38] H. M. Guzmán, P. A. G. Barnes, C. E. Lovelock, and I. C. Feller, "A site description of the CARICOMP mangrove, seagrass and coral reef sites in Bocas del Toro, Panama," Caribbean Journal of Science, vol. 41, no. 3, pp. 430-440, 2005.

[39] L. E. Urrego, E. C. Molina, J. A. Suárez, H. Ruiz, and J. Polanía, "Distribución, composición y estructura de los manglares del golfo de Urabá," in Expedición Estuarina, Golfo de Urabá, Fase 1; Expedición Antioquia 2013, J. F. Blanco, M. Londoño, L. Urrego et al., Eds., chapter 3, pp. 82-110, Gobernación de Antioquia, Universidad de Antioquia, Universidad Nacional de Colombia, Universidad EAFIT, Medellín, Colombia, 2010.

[40] J. F. Blanco and M. C. Castaño, "Efecto de la conversión del manglar a potrero sobre la densidad y tallas de dos 
gasterópodos en el delta del río Turbo (golfo de Urabá, Caribe colombiano)," Revista de Biologia Tropical, vol. 60, no. 4, 2012.

[41] V. Amortegui, Intervención antrópica (potrerización) en rodales de mangle negro Avicennia germinans (Magnoliopsida: Avicenniaceae) en relación a la distribución y abundancia de Neritina virginea (Gastropoda: Neritidae) en el golfo de Urabá, Caribe colombiano [BSc thesis], Universidad de Antioquia, Antioquia, Colombia, 2011.

[42] CORPOURABA, "Caracterización y zonificación de los manglares del Golfo de Urabá-Departamento de Antioquia," Proyecto Zonificación y Ordenamiento de los manglares de Urabá, Convenio 201671, FONADE-CORPOURABA, Apartadó, Colombia, 2003.

[43] C. García, Ed., "Atlas del golfo de Urabá: una mirada al Caribe de Antioquia y Chocó," Instituto de Investigaciones Marinas y Costeras-Invemar- y Gobernación de Antioquia, Serie de Publicaciones Especiales de Invemar no. 12, Santa Marta, Colombia, 2007.

[44] J. F. Blanco, "Banana crop expansion and increased riverborne sediment exports to the Gulf of Uraba, caribbean coast of Colombia," Ambio, vol. 38, no. 3, pp. 181-183, 2009.

[45] I. D. Correa and G. Vernette, "Introducción al problema de la erosión litoral de Urabá (sector Arboletes-Turbo) costa Caribe colombiana," Boletín de Investigaciones Marinas y Costeras, vol. 33, pp. 7-28, 2004.

[46] F. Dahdouh-Guebas, S. Hettiarachchi, S. Sooriyarachchi et al., "Transitions in ancient inland freshwater resource management in Sri Lanka affect biota and human populations in and around coastal lagoons," Current Biology, vol. 15, no. 6, pp. 579-586, 2005.

[47] O. Mohamed, G. Neukermans, J. Kairo, F. Dahdouh-Guebas, and N. Koedam, "Mangrove forests in a peri-urban setting: the case of Mombasa (Kenya)," Wetlands Ecology and Management, vol. 17, no. 3, pp. 243-255, 2009.

[48] R. E. Sherman, T. J. Fahey, and P. Martinez, "Spatial patterns of biomass and aboveground net primary productivity in a mangrove ecosystem in the Dominican Republic," Ecosystems, vol. 6, no. 4, pp. 384-398, 2003.

[49] J. B. Kauffman, C. Heider, T. G. Cole, K. A. Dwire, and D. C. Donato, "Ecosystem carbon stocks of micronesian mangrove forests," Wetlands, vol. 31, no. 2, pp. 343-352, 2011.

[50] ECOFOREST, "Evaluación general del manglar, Golfo de Urabá. Informe principal," Contrato No 056/88, INDERENA REGIONAL ANTIOQUIA-ECOFOREST, Turbo, Colombia, 1990.

[51] A. Arroyave, Exportación de sedimentos desde cuencas hidrográficas de la vertiente oriental del Golfo de Urabá (Caribe colombiano) y su relación con factores climáticos y antrópicos [BSc thesis], Universidad de Antioquia, Antioquia, Colombia, 2011.

[52] A. Etter and W. Van Wyngaarden, "Patterns of landscape transformation in Colombia, with emphasis in the Andean region," Ambio, vol. 29, no. 7, pp. 432-439, 2000.

[53] L. López-Hoffman, I. E. Monroe, E. Narváez, M. MartínezRamos, and D. D. Ackerly, "Sustainability of mangrove harvesting: how do harvesters' perceptions differ from ecological analysis?" Ecology and Society, vol. 11, no. 2, article 14, 2006.

[54] F. Dahdouh-Guebas, I. Van Pottelbergh, J. G. Kairo, S. Cannicci, and N. Koedam, "Human-impacted mangroves in Gazi (Kenya): predicting future vegetation based on retrospective remote sensing, social surveys, and tree distribution," Marine Ecology Progress Series, vol. 272, pp. 77-92, 2004.
[55] C. Tovilla and G. Lanza, "Ecología, producción y aprovechamiento del mangle Conocarpus erectus L., en Barra de Tecoanapa Guerrero, México," Biotropica, vol. 31, no. 1, pp. 121-134, 1999.

[56] R. R. Twilley, R. H. Chen, and T. Hargis, "Carbon sinks in mangroves and their implications to carbon budget of tropical coastal ecosystems," Water, Air, and Soil Pollution, vol. 64, no. 1-2, pp. 265-288, 1992.

[57] E. Kristensen, S. Bouillon, T. Dittmar, and C. Marchand, "Organic carbon dynamics in mangrove ecosystems: a review," Aquatic Botany, vol. 89, no. 2, pp. 201-219, 2008.

[58] A. Komiyama, E. O. Jin, and S. Poungparn, "Allometry, biomass, and productivity of mangrove forests: a review," Aquatic Botany, vol. 89, no. 2, pp. 128-137, 2008.

[59] A. Komiyama, S. Poungparn, and S. Kato, "Common allometric equations for estimating the tree weight of mangroves," Journal of Tropical Ecology, vol. 21, no. 4, pp. 471-477, 2005.

[60] C. E. Lovelock, R. W. Ruess, and I. C. Feller, " $\mathrm{Co}_{2}$ efflux from cleared mangrove peat," PLoS ONE, vol. 6, no. 6, Article ID e21279, 2011.

[61] L. C. Roth, "Hurricanes and mangrove regeneration: effects of Hurricane Joan, October 1988, on the vegetation of Isla del Venado, Bluefields, Nicaragua," Biotropica, vol. 24, no. 3, pp. 375-384, 1992.

[62] C. Elster, "Reasons for reforestation success and failure with three mangrove species in Colombia," Forest Ecology and Management, vol. 131, no. 1-3, pp. 201-214, 2000.

[63] L. Perdomo, I. Ensminger, L. F. Espinosa, C. Elster, M. Wallner-Kersanach, and M. L. Schnetter, "The mangrove ecosystem of the Cienaga Grande de Santa Marta (Colombia): observations on regeneration and trace metals in sediment," Marine Pollution Bulletin, vol. 37, no. 8-12, pp. 393-403, 1999.

[64] C. Piou, I. C. Feller, U. Berger, and F. Chi, "Zonation patterns of Belizean offshore mangrove forests 41 years after a catastrophic hurricane," Biotropica, vol. 38, no. 3, pp. 365374, 2006.

[65] J. M. Sharpe, "Responses of the mangrove fern Acrostichum danaeifolium Langsd. \& Fisch. (Pteridaceae, Pteridophyta) to disturbances resulting from increased soil salinity and Hurricane Georges at the Jobos Bay National Estuarine Research Reserve, Puerto Rico," Wetlands Ecology and Management, vol. 18 , no. 1 , pp. 57-68, 2010.

[66] W. A. Gould, G. González, and G. Carrero Rivera, "Structure and composition of vegetation along an elevational gradient in Puerto Rico," Journal of Vegetation Science, vol. 17, no. 5, pp. 653-664, 2006.

[67] E. Medina, E. Cuevas, M. Popp, and A. E. Lugo, "Soil salinity, sun exposure, and growth of Acrostichum aureum, the mangrove fern," Botanical Gazette, vol. 151, no. 1, pp. 41-49, 1990.

[68] F. Dahdouh-Guebas, L. P. Jayatissa, D. Di Nitto, J. O. Bosire, D. L. Seen, and N. Koedam, "How effective were mangroves as a defence against the recent tsunami?" Current Biology, vol. 15, no. 12, pp. R443-R447, 2005.

[69] L. E. Urrego, G. Bernal, and J. Polanía, “Comparison of pollen distribution patterns in surface sediments of a Colombian Caribbean mangrove with geomorphology and vegetation," Review of Palaeobotany and Palynology, vol. 156, no. 3-4, pp. 358-375, 2009.

[70] L. E. Urrego, C. González, G. Urán, and J. Polanía, “Modern pollen rain in mangroves from San Andres Island, Colombian Caribbean," Review of Palaeobotany and Palynology, vol. 162, no. 2, pp. 168-182, 2010. 
[71] K. Mehltreter and M. Palacios-Rios, "Phenological studies of Acrostichum danaeifolium (Pteridaceae, Pteridophyta) at a mangrove site on the Gulf of Mexico," Journal of Tropical Ecology, vol. 19, no. 2, pp. 155-162, 2003.

[72] J. A. Jimenez, "A hypothesis to explain the reduced distribution of the mangrove Pelliciera rhizophorae Tr. \& Pl.," Biotropica, vol. 16, no. 4, pp. 304-308, 1984.

[73] C. Jaramillo and G. Bayona, "Mangrove distribution during the Holocene in Tribuga Gulf, Colombia," Biotropica, vol. 32, no. 1, pp. 14-22, 2000.

[74] L. D. Lacerda, J. E. Conde, B. Kjerfve, R. Álvarez-León, C. Alarcón, and J. Polanía, "American Mangrovesp," in Mangrove Ecosystem, Function and Management, L. D. Lacerda, Ed., pp. 1-62, Springer, Berlín, Germany, 2001.

[75] B. A. Polidoro, K. E. Carpenter, L. Collins, N. C. Duke, and A. M. Ellison, "The loss of species: mangrove extinction risk and geographic areas of global concern," PLoS ONE, vol. 5, no. 4, Article ID e10095., 2010.

[76] L. F. Ortiz and J. F. Blanco, “Ámbito de los gasterópodos del manglar Neritina virginea (Neritidae) y Littoraria angulifera (Littorinidae) en la Ecorregión Darién, Caribe colombiano," Revista de Biologia Tropical, vol. 60, no. 1, pp. 219-232, 2012.

[77] J. F. Blanco and J. R. Cantera, "The vertical distribution of mangrove gastropods and environmental factors relative to tide level at Buenaventura Bay, Pacific coast of Colombia," Bulletin of Marine Science, vol. 65, no. 3, pp. 617-630, 1999.

[78] J. F. Blanco and F. N. Scatena, "Floods, habitat hydraulics and upstream migration of Neritina virginea (Gastropoda: Neritidae) in Northeastern Puerto Rico," Caribbean Journal of Science, vol. 41, no. 1, pp. 55-74, 2005.

[79] J. F. Blanco and F. N. Scatena, "Hierarchical contribution of river-ocean connectivity, water chemistry, hydraulics, and substrate to the distribution of diadromous snails in Puerto Rican streams," Journal of the North American Benthological Society, vol. 25, no. 1, pp. 82-98, 2006.

[80] E. C. Proffitt and D. J. Devlin, "Grazing by the intertidal gastropod Melampus coffeus greatly increases mangrove leaf litter degradation rates," Marine Ecology Progress Series, vol. 296, pp. 209-218, 2005.

[81] S. Cannicci, D. Burrows, S. Fratini, T. J. Smith III, J. Offenberg, and F. Dahdouh-Guebas, "Faunal impact on vegetation structure and ecosystem function in mangrove forests: a review," Aquatic Botany, vol. 89, no. 2, pp. 186-200, 2008.

[82] S. Y. Lee, "Mangrove macrobenthos: assemblages, services, and linkages," Journal of Sea Research, vol. 59, no. 1-2, pp. 16-29, 2008.

[83] A. Sasekumar and V. C. Chong, "Faunal diversity in Malaysian mangroves," Global Ecology and Biogeography Letters, vol. 7, no. 1, pp. 57-60, 1998.

[84] E. C. Ashton, D. J. Macintosh, and P. J. Hogarth, "A baseline study of the diversity and community ecology of crab and molluscan macrofauna in the Sematan mangrove forest, Sarawak, Malaysia," Journal of Tropical Ecology, vol. 19, no. 2, pp. 127-142, 2003.

[85] E. S. Diop, C. Gordon, A. K. Semesi et al., "Mangroves of Africap," in Mangrove Ecosystems. Function and Management, L. D. Lacerda, Ed., pp. 63-121, Springer, Berlín, Germany, 2001.

[86] E. N. Fondo and E. E. Martens, "Effects of mangrove deforestation on macrofaunal densities, Gazi Bay, Kenya," Mangroves and Salt Marshes, vol. 2, no. 2, pp. 75-83, 1998.
[87] G. A. Skilleter and S. Warren, "Effects of habitat modification in mangroves on the structure of mollusc and crab assemblages," Journal of Experimental Marine Biology and Ecology, vol. 244, no. 1, pp. 107-129, 2000. 

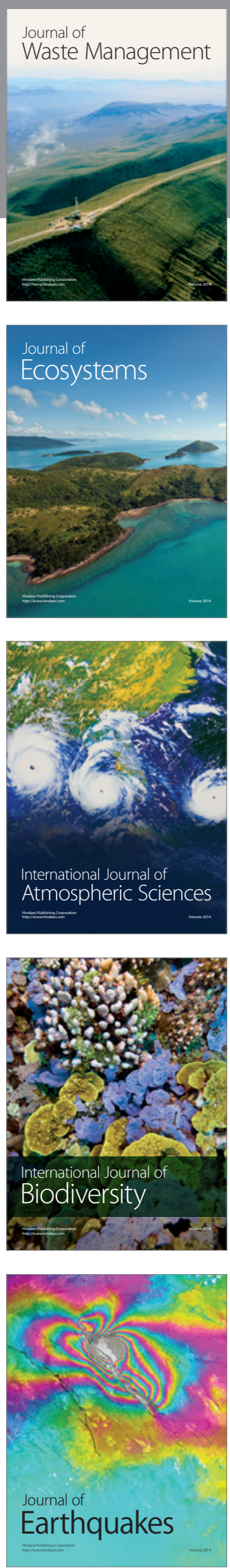
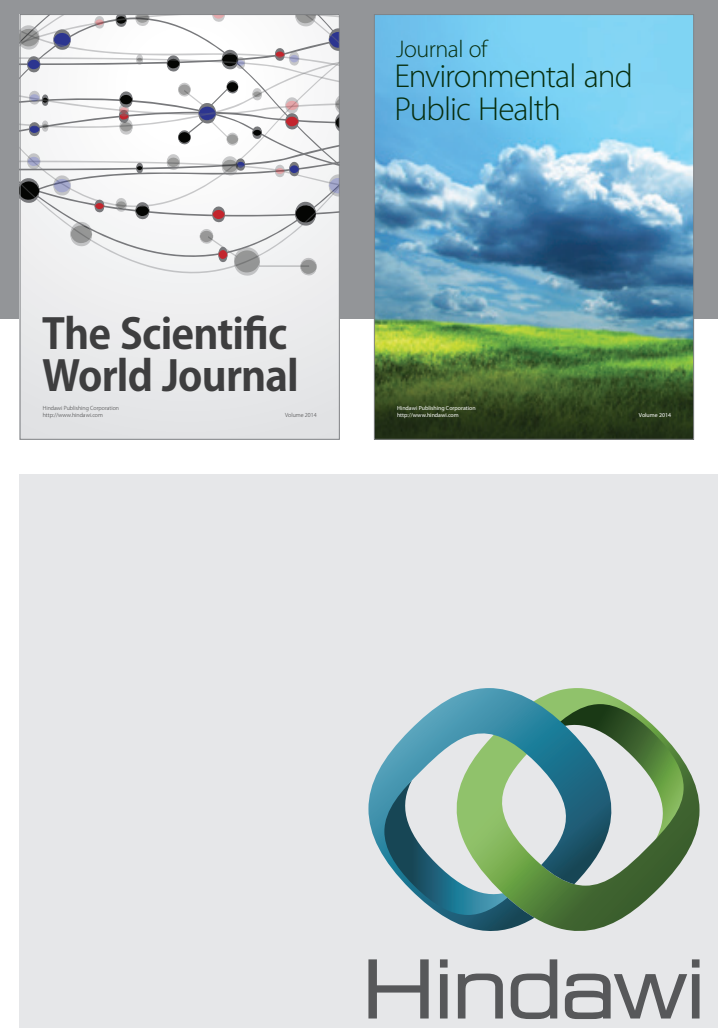

Submit your manuscripts at

http://www.hindawi.com
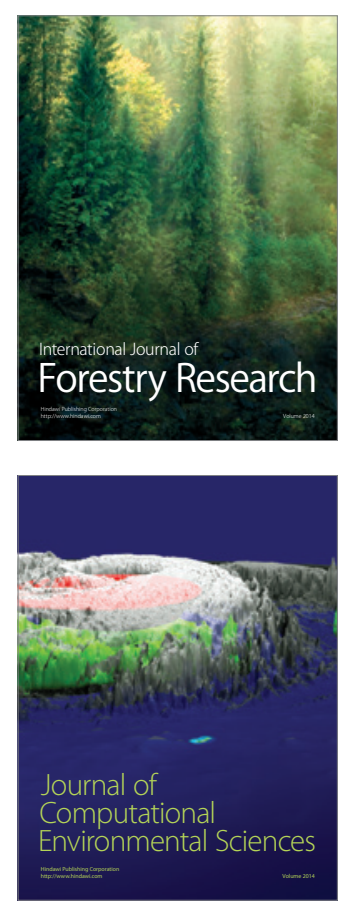
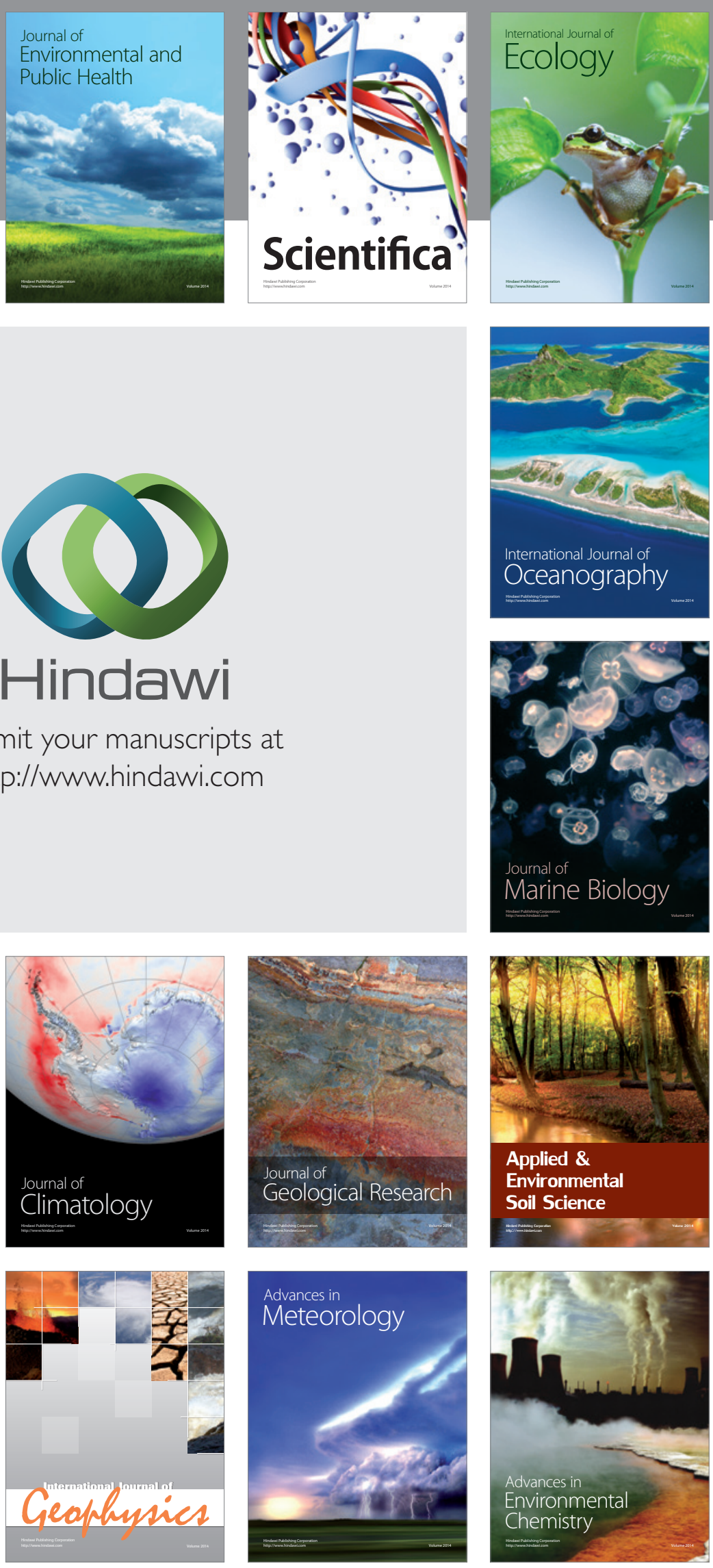